\title{
Ser de um rio sem peixes, de Rosario Castellanos
}

Barbara Zocal Da Silva (USP)

Ser de río sin peces

Ser de río sin peces, esto he sido.

Y revestida voy de espuma y hielo.

Ahogado y roto llevo todo el cielo

y el árbol se me entrega malherido.

A dos orillas del dolor uncido va mi caudal a un mar de desconsuelo.

La garza de su estero es alto vuelo y adiós y breve sol desvanecido.

Para morir sin canto, ciego, avanza mordido de vacío y de añoranza. Ay, pero a veces hondo y sosegado se detiene bajo una sombra pura. Se detiene y recibe la hermosura con un leve temblor maravillado.

\section{Ser de um rio sem peixes}

De um rio sem peixes, isso eu sou.

E revestida de espuma e gelo eu vou. Carrego todo o céu afogado e fatigado e a árvore pungente a mim se rende.

A duas ondas da cingida dor meu leito segue a um mar de desconsolo. A garça de seu esteiro é alto voo e adeus e breve sol quase a se pôr.

Para morrer sem canto, às cegas, seguia mordido de vazio e nostalgia.

Ah, mas por vezes profundo e sossegado se detinha sob a sombra pura. Se detinha, recebia a belezura com um leve frêmito embasbacado.

\section{Notas da tradutora}

A motivação de traduzir o poema "Ser de río sin peces", de Rosario Castellanos, surgiu durante a Oficina de tradução de poesia, ministrada pelo professor e poeta Dirceu Villa em 2017, no Programa Formativo de tradutores literários, ofertado pela Centro de Estudos de Tradução Casa Guilherme de Almeida, em São 
Paulo. Entre as opções de traduzir "Preguntas a la hora del té", do chileno Nicanor Parra, "A una nariz", do espanhol Francisco de Quevedo y Villegas e "Ser de río sin peces", da mexicana Rosario Castellanos, escolhi a poetisa. Ela é considerada uma das escritoras mexicanas mais importantes do século XX, mas suas poesias ainda são desconhecidas no Brasil, apesar de haver pesquisas acadêmicas e livros sobre a autora. A principal referência em língua portuguesa é o livro Uma consciência feminista: Rosario Castellanos, de Beth Miller (Perspectiva, 1987).

Rosario Castellanos Figueroa nasceu na região de Altos de Chiapas em 25 de maio de 1925. A escrita em sua vida surgiu como uma forma de se expressar diante das desventuras que viveu após os falecimentos de seu irmão e seus pais (VERGARA, 2007), quiçá como uma escrita curativa ${ }^{1}$, o que a tornou a primeira mulher escritora de Chiapas. Posteriormente, estabeleceu residência na Cidade do México, onde se graduou em filosofia na Universidad Nacional Autónoma de México (UNMA) em 1950, lecionou nesta mesma universidade e em outras tantas nos Estados Unidos, e trabalhou como chefe da Imprensa na UNMA. Em 1971, nomearam-na embaixadora do México em Tel Aviv, Israel. Lá faleceu tragicamente, em 1975, após ser atingida por uma descarga elétrica enquanto seu corpo estava molhado.

Dona de extensa bibliografia composta de poesia, romances, contos, ensaios, artigos, peças de teatro e epistolário, nos quais explora temas em defesa de indígenas, sem-terra, reforma agrária, personagens mulheres em situações limites que confrontam os valores da sociedade do século XX. Ademais de laureada com vários prêmios de literatura, sua obra vem sendo recentemente redescoberta e republicada no México, por meio da Revista Debate Feminista ${ }^{2}$, pesquisada por acadêmicos brasileiros e, como apresento aqui ainda em fragmento, traduzida ao português brasileiro.

Pelo poema "Ser de río sin peces" não estar presente na coletânea Poesía no eres tú: obra poética (1948-1971), organizada e publicada pelo Fondo de Cultura Económica (2004, $4^{a}$ edição), suponho que a autora o tenha escrito nos seus últimos anos de vida, entre 1972 e 1975, entre seus 47 e 49 anos, em anos de escrita mais madura, após ter conhecido vários países e cidades, e num momento em que

1 Conceito usado a partir de Geruza Zelnys de Almeida, doutora em Teoria Literária e Literatura Comparada pela Universidade de São Paulo, idealizadora e criadora do Curso de Escrita Curativa.

2 Revista Debate Feminista é uma revista semestral editada pelo Centro de Investigaciones y Estudios de Género (UNMA) e que apresenta temas sobre sexualidade e gênero por meio de poemas, partituras, resenhas críticas, fotografias etc. Disponível em: <http://debatefeminista.cieg.unam.mx/>. Acesso em: mar. 2018. 
ela se encontrava em Israel. Lendo-o, o poema me remeteu ao deslocamento, às sensações e relações gélidas.

Tabela 1 - Escansão do poema "Ser de río sin peces", de Rosario Castellanos

\begin{tabular}{|c|c|c|}
\hline $\begin{array}{l}\mathrm{N}^{\mathrm{o}} \text { de } \\
\text { Sílabas }\end{array}$ & $\begin{array}{c}\text { Rima } \\
\text { Consoante }\end{array}$ & Escansão \\
\hline 11 & A & Ser /de /rí/o / sin /pe/ces, /es/to he /si/do. \\
\hline 11 & $\mathrm{~B}$ & $\mathrm{Y} / \mathrm{re} / \mathrm{ves} / \mathrm{ti} / \mathrm{da} /$ voy /de es/pu/ma y /hie/lo. \\
\hline 12 & $\mathrm{~B}$ & A/ho/ga/do y /ro/to /lle/vo /to/do el / cie/lo \\
\hline 11 & A & y el/ár/bol/ se /me en/tre/ga /mal/he/ri/do. \\
\hline 11 & A & A /dos /o/ri/llas /del /do/lor /un/ci/do \\
\hline 11 & B & $\mathrm{va} / \mathrm{mi} / \mathrm{cau} / \mathrm{dal} / \mathrm{a}$ un $/ \mathrm{mar} / \mathrm{de} / \mathrm{des} / \mathrm{con} / \mathrm{sue} / \mathrm{lo}$. \\
\hline 11 & $\mathrm{~B}$ & $\mathrm{La} / \mathrm{gar} / \mathrm{za} / \mathrm{de} / \mathrm{su}$ es/te/ro es/al/to /vue/lo \\
\hline 11 & A & y a/diós /y /bre/ve/sol /des/van/e/ci/do. \\
\hline 11 & $\mathrm{C}$ & $\mathrm{Pa} / \mathrm{ra} / \mathrm{mo} / \mathrm{rir} / \mathrm{sin} / \mathrm{can} / \mathrm{to}, / \mathrm{cie} / \mathrm{go}, \mathrm{a} / \mathrm{van} / \mathrm{za}$ \\
\hline 11 & $\mathrm{D}$ & mor/di/do /de /va/cí/o y /de a/ño/ran/za. \\
\hline 11 & $\mathrm{E}$ & Ay, /pe/ro a /ve/ces/hon/do y /so/se/ga/do \\
\hline 11 & $\mathrm{~F}$ & se /de/tie/ne /ba/jo u/na /som/bra /pu/ra. \\
\hline 11 & $\mathrm{~F}$ & $\mathrm{Se} / \mathrm{de} / \mathrm{tie} / \mathrm{ne} \mathrm{y} / \mathrm{re} / \mathrm{ci} / \mathrm{be} / \mathrm{la} \mathrm{her} / \mathrm{mo} / \mathrm{su} / \mathrm{ra}$ \\
\hline 11 & $\mathrm{E}$ & con/un le/ve /tem/blor/ma/ra/vi/lla/do. \\
\hline
\end{tabular}

Todos os versos são hendecassílabos, a exceção do terceiro - dodecassílabo -, e as rimas são consoantes. Quanto a forma, o poema se trata de um soneto, dois quartetos e dois tercetos. Na tradução apresentada, priorizei o sentido e a rima, em detrimento da métrica.

\section{Referências bibliográficas}

CASTELLANOS, Rosario. Cuaderno no .95 de poesía social: Rosario Castellanos. Barcelona: Biblioteca Virtual Omegalfa, 2015. Disponível em: <https://omegalfa.es/>. Acesso: mar. 2018. 
MILLER, B. Uma consciência feminista: Rosário Castellanos. Trad. de Suzana Vargas e Felipe Fortuna. $1^{\mathrm{a}}$ ed. São Paulo: Perspectiva, 1987.

VERGARA, Gloria. Identidad y memoria en las poetas mexicanas del siglo XX. México, D. F.: Universidad Iberoamericana, 2007. 